\title{
Factors Affecting the Concentration of Faecal Bacteria in Land-drainage Water
}

\author{
By M. R. EVANS AND J. D. OWENS \\ Microbiology Department, West of Scotland Agricultural College, Auchincruive, Ayr
}

(Accepted for publication 24 February 1972)

SUMMARY

The rate of discharge and the concentration of faecal bacteria in the water from a subsurface field drain were monitored, initially for one winter without application of animal excrement to the pasture, and, subsequently, for two winters when pig excrement was sprayed over the pasture. The concentrations of Escherichia coli and enterococci in the water were found to be affected by three main factors: the flow rate of the drain discharge; the number of bacteria in or on the soil and vegetation; and the application to the land of large volumes of semiliquid animal excrement over short periods of time. In the absence of excrement application, the concentration of faecal bacteria in the water was related to the flow rate and to time by an equation of the form: $\log$ bacterial concentration $=a+b \log$ flow rate $-c$ days, where $a, b$ and $c$ are constants. The concentrations of bacteria in the water declined with time, the $90 \%$ reduction times being 57 days for $E$. coli and 96 days for enterococci. The spraying of pig excrement over the pasture resulted in a 30 - to 900-fold increase in the concentrations of faecal bacteria in the drain discharge within $2 \mathrm{~h}$ of the start of the spraying. The concentrations of faecal bacteria returned to their normal levels over a period of 2 to 3 days.

\section{INTRODUCTION}

The tendency in present-day agriculture is towards the increased housing of animals. This frequently leads to the accumulation of their excreta in the form of a semiliquid slurry which is normally disposed of by spraying on to the surface of grassland. Since faeces from farm animals may contain pathogenic intestinal micro-organisms (Taylor \& McCoy, 1969) their disposal could lead to the dissemination of these pathogens in the environment and an increased incidence of animal and human infections.

To determine whether bacteria in animal excrement could pass through soil, into subsurface drains and thence to open water courses, the concentrations of faecal bacteria in drainage water were first monitored in the absence of excrement application to the land. Pig excrement was then applied to the land and the effect on the concentrations of faecal bacteria in the water observed.

\section{METHODS}

The drainage water studied was obtained from the subsurface drainage system of a pasture of about 0.7 ha. The pasture is believed to contain an extensive network of drains consisting of unglazed porcelain segments resting on slate bases. At the lowest part of the pasture the drainage system was interrupted and instruments for sampling and measuring the flow rate of the discharge were installed.

The pasture was last ploughed and reseeded in 1965 . The soil is a sandy clay loam (average analysis down to a depth of $\mathrm{I} \mathrm{m}$ : sand, $62 \%$; silt, $\mathrm{II} \cdot 5 \%$; clay, $23.5 \% ; \mathrm{pH}$ value 6.0 to 6.5 ; 
imperfectly draining). During summer 1968 until 15 October the pasture was grazed by cattle and sheep. In addition to the faeces from these animals $40 \mathrm{~m}^{3} / \mathrm{ha}$ of pig excrement was applied to the land in this period. No animals were present and no excrement was applied during winter I968/9. The pasture was again grazed during summers 1969 and 1970. No animals were present but pig excrement was sprayed over the surface of the pasture from a vacuum tanker three times during winter 1969/70 and twice during winter 1970/I.

The rate of discharge of water from the drain was continuously monitored with a $V$ notch weir gauge (Evans \& Edgar, I97I). During winter 1968/9 samples of the discharge were taken with either an Interval Liquid Sampling machine modified to pump at $\mathrm{I} \mathrm{cm}^{3} / \mathrm{s}$ (Rock \& Taylor Ltd, 3I -46 Waterall Lane, Cradley Heath, Warley) or a Lea Sampling Machine (Lea Recorder Co. Ltd, Cornbrook Park Road, Manchester I5). Both machines take samples at hourly intervals and the samples from each $24 \mathrm{~h}$ period were collected in a single sterile 51 bottle. During winter I969/70 a sample was collected each day using the continuous sampler described by Evans \& Edgar (I97I). For the experiments on the effect of slurry application done during winter 1970/I water samples were collected in sterile evacuated Winchester bottles with an attached length of silicone-rubber tubing (cf. Zobell, I94I). No samples were collected during spring or summer because no water was discharged from the drain in these periods.

Records of daily rainfall and of atmospheric temperatures were obtained from two meteorological stations, one (Auchincruive) situated $\mathrm{I} \mathrm{km}$ south-west of the experimental plot and the other (Prestwick) $2 \mathrm{~km}$ due north.

Bacteriological examination and determination of the $\mathrm{pH}$ value of water samples were carried out within 30 min of collection, while samples for chemical analysis were stored at $5{ }^{\circ} \mathrm{C}$ from I to $72 \mathrm{~h}$ before being analysed. Numbers of viable Escherichia coli and enterococci in water samples were determined by the membrane filtration technique, using Sartorius MF 30 membranes (supplied by V. A. Howe Co. Ltd, 46 Pembridge Road, London W.II). Escherichia coli were cultured on $m$-endo broth Mf (Difco) at $37^{\circ} \mathrm{C}$ for $24 \mathrm{~h}$ and enterococci were cultured on $m$-enterococcus agar (Difco) at $37^{\circ} \mathrm{C}$ for $48 \mathrm{~h}$. Numbers of viable coliform bacteria in the pig excrement were determined, after blending in an Atomix blender (M.S.E. Ltd, 25-28 Buckingham Gate, London, S.W. I) at maximum speed for $2 \mathrm{~min}$, by the dilution tube technique using McConkey broth (Oxoid CM5a). A proportion of the E. coli cultures from membrane filters and coliform cultures from dilution tubes were tested and confirmed as $E$. coli by the Eijkman and IMVIC tests. Gram-stained smears were made from a proportion of the colonies on enterococcus agar and those colonies consisting of Gram-positive cocci were taken to be enterococci.

Concentrations of biochemical oxygen demand, nitrate, and suspended solids in the water samples and piggery waste slurry were determined by standard methods (Ministry of Housing and Local Government, I956).

\section{RESULTS}

\section{Effect of flow rate of the drain discharge on the concentrations of faecal bacteria}

During winter I $968 / 9$ no animals were present on the pasture and no excrement was applied to it. Thus the results (Fig. I) show the relationship between flow rate of the discharge and the concentrations of faecal bacteria in the discharge in the absence of further inoculation of the soil with faecal bacteria. Escherichia coli and enterococci were consistently isolated from the drain discharge over the entire period of winter I968/9 at concentrations ranging from $2 \times \mathrm{IO}^{1}$ to $\mathrm{IO}^{5} E$. coli/l and $\mathrm{IO}^{1}$ to $\mathrm{I}^{\cdot} 4 \times \mathrm{IO}^{4}$ enterococci/l. More than $97 \%$ of the presumptive $E$. coli colonies from the membrane filters examined proved to be $E$. coli. Since 


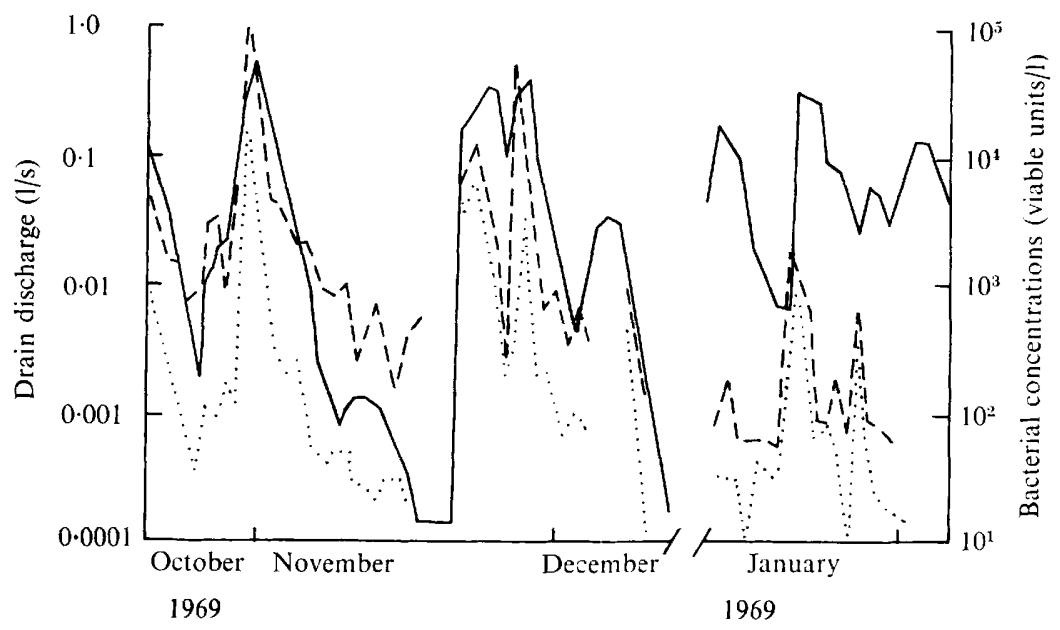

Fig. I. Flow rate of drain discharge (continuous line) and concentrations of Escherichia coli (dashed line) and enterococci (dotted line) in the discharge during winter I968/9.

it is generally accepted that this organism is of exclusively faecal origin and does not multiply in soil or on vegetation (Ministry of Health and Social Security, 1969) those present in the drain discharge are presumed to have originated from faecal material applied to the pasture during the summer. All colonies from enterococcus agar that were examined were enterococci, and are also presumed to have originated from faecal material applied during the summer. It is clear, therefore, that $E$. coli and enterococci isolated from the drain discharge in February 1969 had survived in or on the pasture for at least 4 months.

It is evident from Fig. I that the concentrations of coliform bacteria and enterococci in the discharge water were high at high flow rates and lower at low flow rates. Regression analysis showed that $\log$ concentration of bacteria in the discharge is related to log flow rate of the discharge and to number of days after I October I 968 by an equation of the form $Y=a+b X-c Z$, where $Y=\log _{10}$ concentration of bacteria in the discharge, viable units $/ 1$; $X=\log _{10}$ flow rate of the discharge, $1 / \mathrm{s} ; Z=$ number of days after I October 1968; and $a$, $b$ and $c$ are constants. For Escherichia coli the equation giving the best fit is

and for enterococci

$$
Y=4.84+0.52 \mathrm{I}( \pm 0.055) X-0.0176( \pm 0.0015) Z
$$

$$
Y=3.96+0.701( \pm 0.064) X-0.0104( \pm 0.0017) Z
$$

the figures in parentheses being the standard errors of the regression coefficients.

The equation for Escherichia coli accounts for $77 \%$ of the variation observed in the concentration of bacteria in the discharge, and that for enterococci accounts for $70 \%$. No improvement was obtained by attempting to allow the regression coefficient, $b$, on flow rate to change with time, and no relationship was detected between bacterial concentration in the discharge and variation in atmospheric temperature. Thus it seems probable that the concentration of bacteria in the discharge is determined mainly by those factors included in the regression equations. 

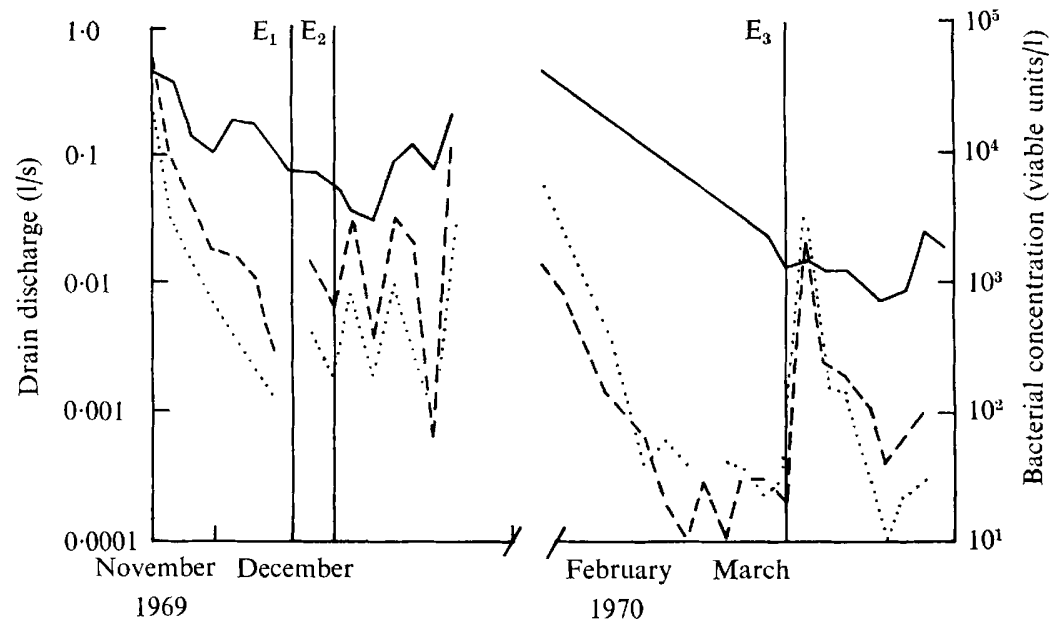

Fig. 2. Flow rate of drain discharge (continuous line) and concentrations of Escherichia coli (dashed line) and enterococci (dotted line) in the discharge during winter $1969 / 70$. Vertical lines, E, indicate days when pig excrement was applied to the pasture $\left(E_{1}, 22 \mathrm{~m}^{3} / \mathrm{ha} ; E_{2}, 33 \mathrm{~m}^{3} / \mathrm{ha} ; E_{3}, 55 \mathrm{~m}^{3} / \mathrm{ha}\right)$.

\section{Relationship between time since application of animal excrement to the land and concentrations of faecal bacteria in the drain discharge}

The time factor, $c$ number of days after I October I968, in the regression equation indicates that the concentration of viable bacteria in the drain discharge declined logarithmically with time, as one might expect for types of bacteria believed to be incapable of multiplication in water or soil. The values of coefficient $c$ show that the $90 \%$ reduction time for Escherichia coli was 57 days while that for enterococci was 96 days.

\section{Effect of slurry application on the concentrations of faecal bacteria in the drain discharge}

During winter $1969 / 70$ the flow rate of the discharge was monitored continuously and the numbers of faecal bacteria were determined in daily samples of the discharged water as during winter $1968 / 9$, but in addition pig excrement was applied to the pasture on three occasions. As in winter 1968/9, the concentrations of Escherichia coli and enterococci in the drain discharge varied with the flow rate of the discharge (Fig. 2). However, after the application of excrement the 'normal' relationships between bacterial concentration and flow rate were disturbed, and the concentrations of faecal bacteria in the discharge were higher in the water sample collected the day following the excrement application than in the sample collected on the day of excrement application, even though the flow rate was lower. On each occasion, 2 days after the excrement had been applied the concentrations of faecal bacteria in the discharge had practically returned to the 'normal' value appropriate to the flow rate of the discharge.

It was clear from these results that it would be useful, after applying excrement to the pasture, to sample the drain discharge more frequently than once daily. So, during winter I970/I pig excrement (approximate composition: suspended solids, I20 g/1; biochemical oxygen demand, $35 \mathrm{~g} / 1 ; \mathrm{pH}$ value, $8.7 ;$ Escherichia coli, $\left.9 \times 10^{8} / 1\right)$ was applied to the land at a rate of $33 \mathrm{~m}^{3} /$ ha on 28 October (Expt A) and on 23 November (Expt B). Water samples were collected at intervals of 0.5 to $4 \mathrm{~h}$ for about $36 \mathrm{~h}$ following the excrement application. 


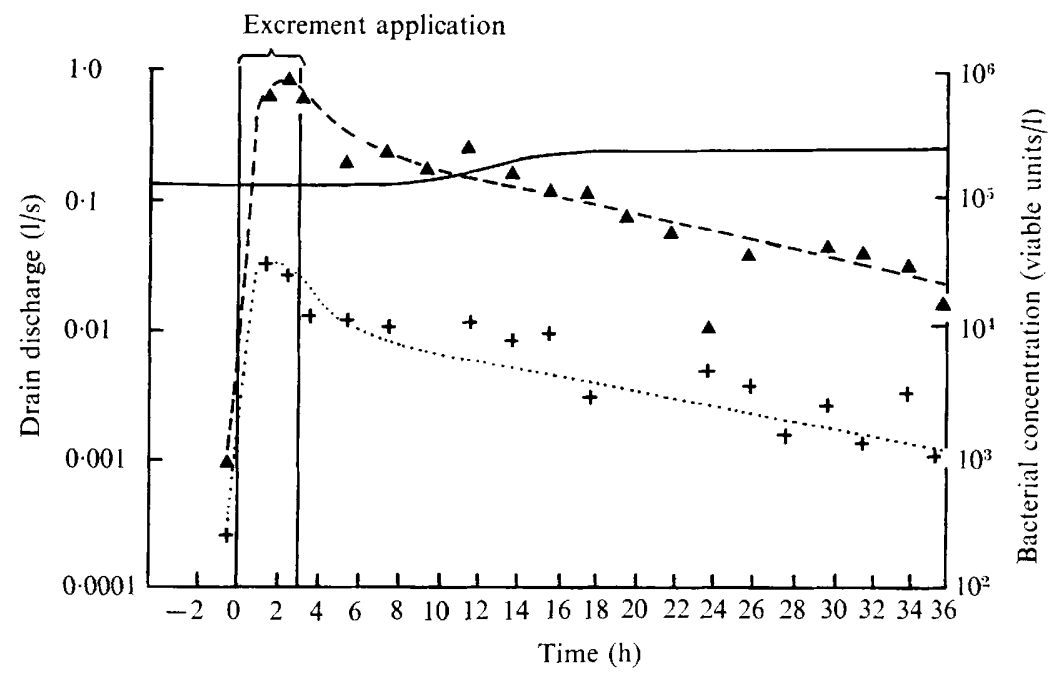

Fig. 3. Flow rate of drain discharge (continuous line) and concentrations of Escherichia coli (dashed line) and enterococci (dotted line) in the discharge during $36 \mathrm{~h}$ following the application of pig excrement, $55 \mathrm{~m}^{3} / \mathrm{ha}$, to the pasture (Expt A).

Experiment $A$. The flow rate of the drain discharge and the concentrations of faecal bacteria in the drainage water following the application of excrement to the pasture are shown in Fig. 3. The flow rate of the drain discharge was steady for the first in $\mathrm{h}$ following the start of the excrement application and then increased slightly during the rest of the experimental period, possibly as a result of rain which fell during the experiment.

Within 90 min of starting to apply excrement the concentration of Escherichia coli in the water had increased 900 -fold from $\mathrm{I} \times 10^{3} / 1$ to $9 \times 10^{5} / 1$ and that of enterococci 150 -fold from $2 \times \mathrm{IO}^{2} / 1$ to $3 \times \mathrm{IO}^{4} / 1$. The concentrations of both types of bacteria then steadily declined until the experiment was stopped because the flow rate of the discharge increased markedly following heavy rain. By this time the concentrations of faecal bacteria in the discharge were only about 5 to ro times the concentrations that would be expected in the absence of excrement application, after allowance for the increase in flow rate.

Experiment $B$. The results obtained in the second experiment are shown in Fig. 4 . On this occasion the excrement was applied to the land in two periods separated by a $\mathrm{I} h$ interval, instead of in a single period as in Expt $\mathrm{A}$, and the flow rate of the discharge was higher. Since the flow rate of the discharge declined during the period of the experiment and was apparently unaffected by the application of excrement it is clear that the volume of excrement applied must have been small relative to the volume of water held in the soil.

Within $2 \mathrm{~h}$ of the start of excrement application the concentration of Escherichia coli in the discharge had increased 6o-fold from $8 \times 10^{2} / 1$ to $5 \times 10^{4} / 1$ and that of enterococci 20 -fold from $\mathrm{I} \cdot 5 \times \mathrm{IO}^{2} / 1$ to $3 \times \mathrm{IO}^{3} / \mathrm{l}$. The concentrations of bacteria in the drain discharge then declined before increasing again approximately $3 \mathrm{~h}$ after the start of the second period of excrement application. The concentrations then declined until at the end of the experiment they were practically at levels existing before excrement was applied.

\section{Chemical pollutants in the drain discharge}

During the winters $1968 / 9$ and 1969/70 the samples of drain discharge were generally clear and colourless. The $\mathrm{pH}$ was near neutrality, the biochemical oxygen demand was generally 


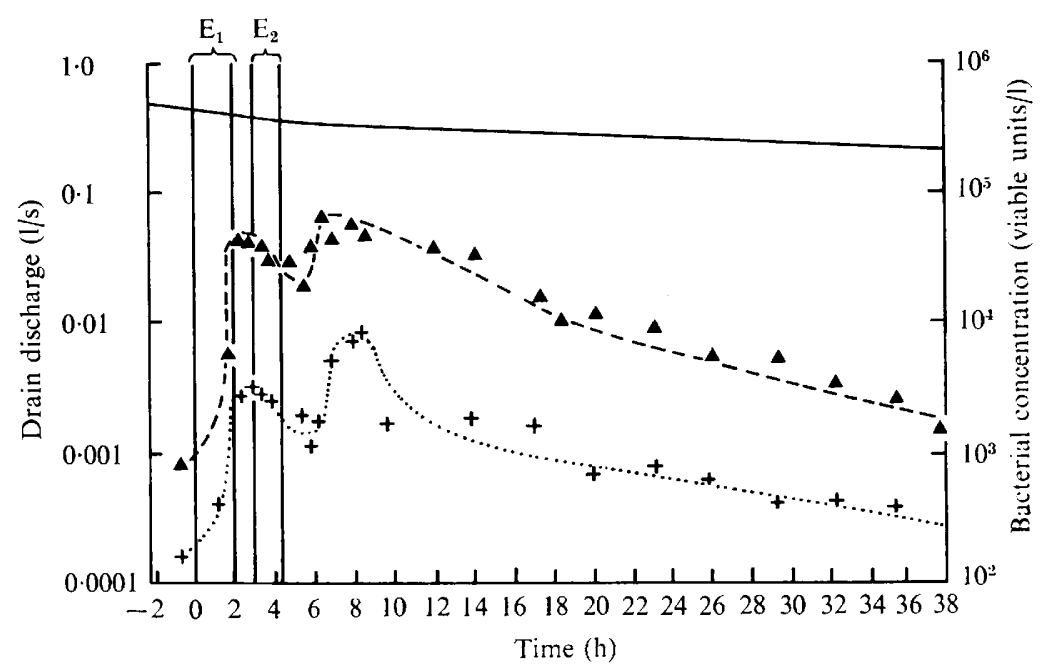

Fig. 4. Flow rate of the drain discharge (continuous line) and concentrations of Escherichia coli (dashed line) and enterococci (dotted line) in the discharge during $38 \mathrm{~h}$ following the application of pig excrement, $55 \mathrm{~m}^{3} /$ ha, to the pasture (Expt $\mathrm{B}$ ). $\mathrm{E}_{1}$ and $\mathrm{E}_{2}$ indicate periods during which excrement was applied.

less than $3 \mathrm{mg} / \mathrm{l}$, the suspended solids concentration less than $5 \mathrm{mg} / \mathrm{l}$ and the nitrate concentration less than $3 \mathrm{mg} / \mathrm{l}$.

In Expt A (October 1970), after the application of excrement to the pasture, the first water samples were slightly turbid and pale brown in colour but later samples were clear and colourless. The biochemical oxygen demand of the discharge increased slightly reaching a maximum of $14 \mathrm{mg} / \mathrm{l}$, I $\mathrm{h}$ after the start of excrement application, while the suspended solids concentration and nitrate concentration were unaffected. The $\mathrm{pH}$ value increased by up to half a unit for about $24 \mathrm{~h}$ following the excrement application.

During Expt B (November 1970) the biochemical oxygen demand, suspended solids concentration and nitrate concentration remained at their normal low levels. In this experiment all the water samples were clear and colourless and the $\mathrm{pH}$ value of the discharge increased by only $\mathrm{O} \cdot \mathrm{I}$ unit for about $8 \mathrm{~h}$ following the start of excrement application.

\section{DISCUSSION}

These studies show that subsurface land-drainage water can contain appreciable numbers of faecal bacteria, and that the concentrations of faecal bacteria in the water may be related to the flow rate of the drain discharge and the time since application of animal excrement to the land. Since the faecal bacteria in the water are presumed to have originated either from faeces deposited on the land by grazing animals, or from slurry sprayed on to the land, it is reasonable to suppose that changes in the concentrations of bacteria in the drainage water reflect changes in the numbers or condition of bacteria in or on the soil and vegetation. Thus the results may be interpreted as indicating that the concentration of faecal bacteria in the subsurface drainage water from a pasture may be affected by three main factors: (i) the flow rate of water through the soil; (ii) the numbers of faecal bacteria in or on the soil and vegetation; and (iii) the application to the land of large volumes of semiliquid animal excrement over short periods of time. Other factors may also be important. It is likely, for instance, 
that the soil type would exert some influence, but since our studies were limited to one field, we are not able to evaluate the importance of this factor.

Although this work was confined to a study of the factors affecting the concentration of certain faecal bacteria in drainage water, it is reasonable to assume, and preliminary results support this assumption, that other bacteria present in soil, but not growing, would behave similarly. Such bacteria could include organisms that are inherently unable to multiply in soil, such as most intestinal pathogens, as well as normal soil organisms at times of the year when multiplication was precluded by nutrient deficiency or low temperature.

\section{Relationship of concentration of bacteria to flow rate of the discharge}

The results show that, in the absence of recent applications of large volumes of slurry to the land, the concentrations of faecal bacteria in the drain discharge are related to the flow rate of the discharge by an equation of the form: $\log$ bacterial concentration $=a+b \log$ flow rate $-c$ days. If the time factor ( $c$ days) in the equation is ignored it is seen that the relationship between bacterial concentration and flow rate is described by a linear log-log equation having a slope defined by regression coefficient $b$. The values of coefficient $b$ show that for a tenfold increase in flow rate the concentration of Escherichia coli in the drain discharge increased 3.3 -fold while that of enterococci increased by $5^{\circ} 0$-fold. Possibly, the value of this coefficient is related to the relative ease or difficulty with which bacteria attached to soil particles can be liberated into water percolating through the soil. If so then the value of the coefficient would be expected to be related to soil type. Since the coefficient for coliform bacteria is significantly different from that for enterococci $(P=0.001)$, the intensity of the interaction between the bacterial cells and the soil particles must also depend on the nature of the particular bacterial cells.

The existence of this linear log-log relationship is noteworthy because Leopold \& Miller (I956) found that the relationship between the amount of sediment carried by streams and flow rate was also linear $\log -\log$. Thus, although in the present work we are dealing with living cells very much smaller than most of the particles making up sediment in streams, it seems possible that the rate at which bacterial cells are washed out of soil by percolating water may be determined by factors similar to those that determine the rate at which streams and rivers acquire suspended sediment.

Apart from a paper by Leininger \& McCleskey (1953) there is little information available on the relationship between bacterial concentration and the flow rate of rivers and streams. These authors did not observe a constant relationship between faecal bacterial concentrations and rainfall: in some instances bacterial concentrations were higher at times of high rainfall than at times of low rainfall and in others the reverse was true.

\section{Effect of numbers of faecal bacteria in soil on concentrations in drainage water}

In the absence of further additions of faeces, the numbers of viable faecal bacteria in or on the soil and vegetation at any time must depend on: (i) the numbers originally deposited on the land; and (ii) the rate at which viable organisms are lost from the land by death and/or wash-out. Since no attempt was made to determine the numbers of faecal bacteria in the soil, we have no direct information on the relationship between bacterial numbers in the soil and bacterial concentrations in the drainage water. However, it seems likely that the value of constant $a$ in the regression equation (i.e. $\log _{10}$ bacterial concentration when the flow rate is $\mathrm{I} 1 / \mathrm{s}$ and $z$ is zero days) would, in some manner, relate to the numbers of bacteria in the soil and vegetation. In this connexion, it may be significant that the value of constant $a$ is 
higher for Escherichia coli than for enterococci, as $E$. coli is generally more numerous in animal faeces than are enterococci.

The time factor ( $c$ days) in the regression equation can then be interpreted as a correction factor for constant $a$, to take account of the decline in the numbers of viable bacteria in the soil with time. This decline could be due either to death and consumption by predators of bacteria in the soil or to progressive wash-out of bacteria from the soil or to both. Again, since faecal bacteria in the soil were not counted, we are not able to evaluate the relative importance of these possibilities.

The $90 \%$ reduction times for the bacteria in the drain discharge (57 days for Escherichia coli and 96 days for enterococci) are more than four times longer than those recorded by van Donsel, Geldreich \& Clarke (1967) for E. coli and Streptococcus faecalis var. liquifaciens that had been inoculated into soil. These authors recorded maximum $90 \%$ reduction times of $13 \cdot 4$ days for E. coli and $20 \cdot 1$ days for S. faecalis.

\section{Effect of excrement application on the concentration of faecal bacteria in drainage water}

The application of large volumes of semiliquid animal excrement to the land over short periods of time caused very large increases in the concentrations of faecal bacteria in the drainage water, without any accompanying increase in the flow rate. The differences in the results between Expts $\mathrm{A}$ and $\mathrm{B}$, that is the absence of turbidity and colour, the lower increase in $\mathrm{pH}$ value, and the lower maximum concentrations of faecal bacteria in the discharge in Expt B as compared with Expt A, are thought to be due to greater dilution of the excrement by ground water in Expt B than in Expt A, or to the interrupted application of excrement to the land in Expt B.

Although the concentrations of faecal bacteria in the drainage water showed large increases following slurry application, biochemical oxygen demand increased only slightly and no increases in the concentration of suspended solids were detected. This relative lack of suspended solids and biochemical oxygen demand in the drain discharge after excrement application is attributed to the combined effects of filtration and of adsorption of solid material to soil particles, and to the relative insensitivity of the tests for suspended solids and biochemical oxygen demand in comparison with methods for determining viable numbers of bacteria.

The results of the experiments during winter 1969/70 and during winter 1970/I demonstrate clearly that faecal bacteria present in pig excrement can pass through soil into subsurface drains within a few hours of the application of excrement to the field. It is reasonable to assume that if viable pathogenic bacteria were present in the excrement they also would appear in drainage water, and the short time interval between application of excrement and the appearance of faecal bacteria in the drainage water makes it likely that such intestinal pathogens would remain viable.

The total numbers of Escherichia coli discharged in the drain water in the $36 \mathrm{~h}$ following the start of excrement application (Expts A and B) and a rough estimate of the total number applied to the land in the excrement are shown in Table I. Comparison of these figures suggest that the numbers of viable $E$. coli discharged in the drain represented about $\mathrm{I}$ in 3000 in Expt A and $I$ in 2000 in Expt B of those applied. This yielded maximum concentrations of $E$. coli in the water in excess of $10^{5}$ viable units/l. The value of this fraction and the concentrations of $E$. coli in the discharge would obviously be expected to vary with soil type and there are dangers in trying to draw general conclusions on the basis of this one field. Nevertheless, these results do suggest that if excrement containing pathogenic bacteria were spread 
Table I. Estimation of the fraction of Escherichia coli, applied to the pasture in pig excrement, that was discharged in drainage water within $36 \mathrm{~h}$ of the start of application to the pasture

$\begin{array}{lcc} & \text { Expt A } & \text { Expt B } \\ \begin{array}{l}\text { E. coli applied, viable units } \\ \text { Water discharged by drain } \\ \text { within } 36 \mathrm{~h} \text {, (litres) }\end{array} & 2 \times 10^{13} & 2 \times 10^{13} \\ \begin{array}{l}\text { E. coli } \text { discharged in drain } \\ \text { water, viable units }\end{array} & 2 \times 10^{4} & 4 \times 10^{4} \\ \text { Fraction } E \text {. coli } \text { discharged/applied } & 7 \times 10^{9} & 1 \times 10^{10} \\ & 1 / 3000 & 1 / 2000\end{array}$

on to land the concentrations of such bacteria in water could reach levels likely to constitute a health hazard to animals or humans drinking that water. Thus the disposal of increasing quantities of animal excrement on to land as slurries may lead to a significant increase in the level of microbial pollution of the environment.

We thank the Animal Husbandry Experimental Unit, West of Scotland Agricultural College, for providing the pasture and for spraying it with pig excrement; Ayrshire River Purification Board for chemical analyses; Agricultural Research Council Unit of Statistics, University of Edinburgh for statistical analyses. This work forms part of an investigation into the treatment and disposal of farm wastes supported by the Agricultural Research Council.

\section{REFERENCES}

van Donsel, D. J., Geldreich, E. E. \& Clarke, N. A. (1967). Seasonal variations in survival of indicator bacteria in soil and their contribution to storm-water pollution. Applied Microbiology 15, 1362-1370.

Evans, M. R. \& Edgar, R. (I97I). Automatic sampling and measurement of small liquid flows. Water Pollution Control I97 I, I I I-I I3.

LeInINGER, H. V. \& MCCleskey, C. S. (1953). Bacterial indicators of pollution in surface waters. Applied Microbiology I, I I9--I 24.

Leopold, L. B. \& Miller, J. P. (1956). Ephemeral streams: hydraulic factors and their relation to the drainage net. Geological Survey Professional Paper 282-A. Washington: United States Government Printing Office.

Ministry of Health and Social Security (1969). The Bacteriological Examination of Water Supplies, 4th edn. London: Her Majesty's Stationery Office.

Ministry of Housing AND LoCAl Government (1956). Methods of Chemical Analysis as Applied to Sewage and Sewage Effluents, 2nd edn. London: Her Majesty's Stationery Office.

TAYlor, J. \& MCCoy, J. H. (1969). Salmonella and Arizona infections. In Food-borne Infections and Intoxications. Edited by H. Rieman. London: Academic Press.

Zobell, C. E. (194I). Apparatus for collecting water samples from different depths for bacteriological analysis. Journal of Marine Research 4, I73-1 88. 